considerably and the number of candidates successful fell by a third; only 305 out of 978 vacancies were filled, but the balance of departmental needs is met largely by the employment of temporary assistants (scientific), who may thus acquire the period of experience necessary to qualify for establishment by competition.

Difficulty continued in the recruitmont of patent, examiners, and only 17 out of at least 65 vacancies were filled. Only for scientific research fellowships was the situation improved, the number of candidates being up by 50 per cent and the number of fellowships awarded, namely, 27, was nearly doubled. Sixty. eight candidates for research fellowship or seientific officer posts were interviewed in April 1959 in Washington, Ottawa and Now York, in a joint recruiting effort with the Atomic Energy Authority, and as a result 5 research Fellows, 4 senior scientific officors and 2 scientific officers havo taken up duty in the Scientific Civil Service. The number of candidates similarly interviewed during 1960 was more than doubled.

The general situation in the Works Group of the Professional Classes was largely unchanged; the number of vacancies tended to increaso, but the number of candidates was stationary or in some fields tended to decrease. The major shortages are still in civil engineers, quantity surveyors and certain classes of mechanical and electrical engineers, particularly electronics specialists. The Commissioners were concerned with the filling of senior professional posts in the new Inspectorate of Nuclear Installations set up by the Minister of Power, and although unable to fill some of the more specialized posts, they were impressed by the high proportion of applicants who could already claim good experience in nuclear engineering. The Commissioners have still to meet the increase in the demand for architects caused by the formation of the War Department Works Directorate, and in the Technical and Drawing Office Classes there are shortages corresponding to thoso in the professional grade ; candidates corning mainly from within the Service. A shortage of good candidates in tho competition for psychologists is also noted, as well as difficulty in attracting good candidates for posts as librarians in Govornmont dopartments: 12 out of 23 such posts were unfilled.

\title{
TELEVISION AND ADULTS
}

$\mathrm{T}$ O Dr. Hilde Himmelweit's inquiry into the effects of television on children is now added the report of an investigntion into the way television has affected family life*. This inquiry was directed by Dr. W. A. Belson and carried out by the Audienee Research Department of the B.B.C. As is indicated by Prof. M. G. Kendall in an accompanying note, the report can be regarded as providing a roliable account of the effects of television on families.

How television affects farnily lifo is deseribed in a number of ways. Families spend more time at home, particularly during evening transmissions, but therc is a tendency also for viewer's to make up for this by going out more when television is not on. There is some evidence of variation in this pattern according to the area and the seasson, but there is nothing to suggest that these changos are only temporary. Ono kind of family, however, the large family, is exceptional. Television has not increased the degree to which members of bigger families stay together at home : on the evidence of three of the four surveys which were carried out in London, Birmingham and Wakefield at different seasons of the year, television appears in this case to have had the reverse effect.

All four surveys reveal the effect of television to have been to increase the degree to which the married couple stays at home together in the evening period, especially in Wakefield. During the rest of the day the offect varies markedly from survey to survey, couples in some areas going out more after they have acquired television sets. Television's effect in kceping the couple at home together varies with the age of the set, but the particular pattern of change is not the same in each survey.

The effect also varies according to the type of family from which the couple is drawn, those from the

- Television and the Family, (A Roport on an Ermuiry designed and directed by Dr. W. A. Belson, and carried out by the Audience Research Depe. of the B.B.C, under the supervision of Profossor A. R. Knight, M. G. Kendall, P, T. Vernon and Barbarta Wootton. Pp. $x x+151$. (London: British Broadoasting Corporation, 1950.) 'larger families' tending now to spend lesigs time together. The effect of television in keeping them together at home is greater when both are employed than when only one is employed.

Of the effects of television in keeping children and young people at home, the most that can be said is that or balance television tends to result in children and young people spending more time in the homebut not much more. Television's effect on homecentred activity is either small or negligible. 'T'his applies also to the diversity of range of home-centred activity, though the evidence does not rule out shifts in the 'kinds' of activities pursued.

There are distinct differences in the effect of television according to the length of set ownership. While the year-by-year pattern of change in the four surveys differs quite a lot, these patterns exhibit some common tendency to return towards the level of pre-television after about five years. This tendency, however, is neither strong nor undeviating and it may set in after either an earlier increase or an earlier decline. In London, both in summer and winter, and in Birmingham, in winter, television has led to a small reduction in the total amount of joint activity occurring in the home. In summer in Wakefield it increased to a limited extent.

In the early stages of ownership, television may load to either an increase or a decrease in the joint activity in the home, depending on the survey area or the scason. But there is a long-term tendency for the amount of joint activity to return towards the level before television.

Dr. Bclson and his colleagues also examined the effects of tolevision on visiting and entertainment. Ther is an incresse, in all four surveys, in the number of guests in viower households during the average half-hour of the day. The increase is moderate in London in the summer, large in the winter, and large also in Birmingham and Wakefield. The amount of the change varies by time of day, the main 
increase being in the afternoon and evening periods. At its maximum, which is during evening transmission time, the increase is very large, and in some surveys it almost doubles the number of visitors present.

Some of the visitors to viewer homes come as expected guests while others 'drop in' casually. With formal or 'expected' visiting, there is an increase in all four surveys, particularly those dealing with winter behaviour. With casual visiting, however, the increase is limited mainly to London (winter), some of the other surveys producing evidence even of slight reduction. There is a lot of variation in the effect of television according to the length of set ownership, but only with casual visiting is there any consistent trend; in this case it suggests a return towards pre-television level.

The investigators are to be commended not only for the clarity of their report but also for the way they hrve demonstrated the validity of their findings.

\section{UNGULATES OF THE PARC NATIONAL ALBERT}

A PAPER reporting the results of a study of the ecology of the twenty-two species of ungulates living in the Albert National Park in the eastern (Belgian) Congo, carried out from July 1957 to December 1959, forms fascicule I of the "Exploration du Parc National Albert" published by the Institut des Pares Nationaux du Congo Belge " Introduction a l'Ecologie des Ongulés du Parc National Albert", par F. Bourlière et J. Verschuren. Bruxelles, 1960). The report gives a full description of the various habitats that can be found in the $8,090 \mathrm{sq}$. $\mathrm{km}$. of the Park, with emphasis on their geographical, climatic, edaphic and botanical characters, and compares their present state with photographic records of thirty years ago. On the whole there has been no great change, the loss of tree cover in some places being compensated by increases elsewhere. A detailed consideration is given to the geographical distribution of the various species of ungulates (and the elephant) with special attention to their autoecology and food habits. Although many species are plentiful, three-the elephant, hippopotamus, and buffaloare the dominant species, and there is some evidence from a few marked animals that individuals tend to be surprisingly restricted to their territories.
Studies on the density of the ungulate populations were made by regular censuses, and population structure and dynamics are dealt with in separate chapters. During the past thirty years the population of different species has varied in different ways in the same environments. Elephants have increased by immigration, the numbers of hippopotamuses have remained stable, and despite epidemics of rinderpest there has been a spectacular increase in the buffalo population. Other species, such as the topi and the Uganda cob, have increased again after reaching a low level about 1940. Apart from epidemics of rinderpest affecting buffalo, and of anthrax affecting hippopotamus, a number of animals are frequently killed by lethal concentrations of carbon dioxide of volcanic origin. Competition for food in the various environments does not appear to play an important part among the ungulates of the Park.

The authors conclude that on the whole the open plains of the Albert National Park harbour the highest ungulate biomass ever found in Africa. Nevertheless, with the exception of the elephant, the species do not seem to exceed the carrying capacity of the environment. The report is illustrated with forty-nine plates of excellent and well-chosen photographs.

\section{IODIZED SALT AND ENDEMIC GOITRE}

T HE September issue of The Chronicle of the World Health Organization is devoted to endemic goitre (14, No. 9 ; September 1960). The importance of iodized salt as a means of control is well brought out, as are the problems of instituting programmes of mass prophylaxis because of difficulties in manufacturing suitable grades of iodized salt.

Inexpensive and comparatively simple processes are now available which are applicable to any of the usual methods of salt manufacture and give produets stable under exacting climatic conditions. Besides descriptions of the manufacturing methods, optimum dosages of iodized salt for individuals in different areas are reviewed.

The optimum level of iodization of salt depends on the average daily dose of iodine needed to prevent goitre in a community and on the average daily consumption of iodized salt per head. The available evidence suggests that, in endemic goitre areas, each person should receive a daily supplement of about $150 \mu \mathrm{gm}$. of iodine. In some areas, larger supplements (up to 300-400 $\mu \mathrm{gm}$. daily) appear to be necessary, presumably in order to counteract the effect of goitrogenic agents. The consumption per head of salt varies with racial, climatic and other factors; it is higher, for example, in tropical than in temperate climates. It is also necessary to take into account whether all food salt is to be iodized, including that used by food industries, or only table salt.

In the United States, Canada and most countries of Latin America, the level of iodization is based on an estimated average consumption of $6.5 \mathrm{gm}$. per head of table-salt each day, and is calculated to provide a daily supplement of $500 \mu \mathrm{gm}$. of iodine, or $650 \mu \mathrm{gm}$. of potassium iodide. The level is thus $1: 10,000$. In most European countries, much lower levels are used, calculated to supply only the 100 $150 \mu \mathrm{gm}$. of iodine per day estimated to be the body's actual physiological requirements. Thus, in Switzerland, where all food salt is iodized, the level is $1: 100,000$, while in the United Kingdom, where only table salt is iodized, the level is $1: 40,000$. Holman and MeCartney suggest that, for countries with a moderate goitre-rate, the most satisfactory level is 